\title{
Which Type Of Work-Study Experience Is More Beneficial?: Perceptions Of Taiwanese College Students
}

\author{
Cheng Cheng Yang, National Chiayi University, Taiwan \\ Hsuan-Fu Ho, National Chiayi Universiry, Taiwan \\ Shan-Hua Chen, National Chiayi University, Taiwan
}

\begin{abstract}
The rapidly increase of tuition and the reduced financial support from government and families have forced many more students to take part-time jobs, however, different jobs might bear different benefits. The main purpose of this study were to identify the major benefits of part-time jobs or work-study experiences performed by college students, and to calculate the relative weight of each benefits perceived by students, and finally, to determine the most appropriate type of job for college students. A self-developed questionnaire is administered to 250 students from three universities. The results of this study not only help students to select the most appropriate types of job for a given purpose, but also provide school administrators with a guide to develop their student part-time job policies.
\end{abstract}

Keywords: Part-time Job; Work-Study; Higher Education; Finance

\section{INTRODUCTION}

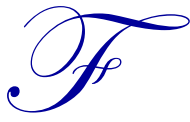

ord, Bosworth, and Wilson (1995) argue in their research that although higher education is traditionally assumed that part-time employment undertaken by full-time undergraduates is incidental, their research results indicate that there are at least $30 \%$ of undergraduates had part-time employment in the year of 1992/93. Moreover, the rapidly increase of tuition and the reduced financial support from government and families have forced many more students to take part-time jobs while enrolled in universities (Miller, 2010; Christou and Haliassos, 2006).

Though college student development theories assert that when college students can devote time on various on-campus and outside-campus activities, they can acquire different abilities and social experiences (Astin, 1999; Kuh, 1995), the effects are still debatable. Although some scholars assert that undergraduates' working experience might have negative effect on students' heath and/or academic performance (Paul, 1982; Laverge, Ledoux, Auclair, Thuilier, Gaudreault, Gaudreault, Veillette, and Perron, 2011), many others finds that the working experience for college students is beneficial for their interpersonal competence, practical competence, cognitive complexity, knowledge and academic skills, and humanitarianism. Moreover, work-studies is beneficial for students' academic outcomes and preparation for the future labor market (Kuh, 1995; Derous, and Ryan, 2008; Pinquart, Juang, and Silbereisen, 2003; Hakkinen, 2006). Ehrenberg and Sherman (1987) find that different type of part-time jobs might lead to different results, and he asserts that on-campus jobs have better effects than off-campus jobs. Gault, Redington, and Schlager (2000) report that when business major undergraduates have internship experience, they would obtain first position in a shorter period of time and have better overall job satisfaction.

This study proposes a different approach to explore the effects of part-time employment during college. Since benefit is a relative measure, and because Analytic Hierarchy Process (AHP) is one of the best methods to acquire relative weights of different attributes, AHP is adopted in this study as the major tool to calculate the relative weights of benefits. Decision making is a process of rating importance and priority. We assert analytic hierarchy process is highly suited for this study. Analytic hierarchy process is adopted in this study to measure the relative 
weights of different benefits of part-time employment experiences among undergraduates in Taiwan. We also designed a self-developed questionnaire to measure the weighted scores of various types of part-time employment on benefits. The results of this study can help college and university administrators make policy decision.

\section{METHODOLOGY}

The main purpose of this study were to identify the benefits pursuit of part-time jobs performed by college students, and then determine their relative weights, and finally determined the most appropriate type of job for college students.

\section{The Analytic Hierarchy Process}

We adopt the Analytic Hierarchy Process as the major instrument for calculating the relative weights of the benefits of part-time jobs because AHP has several advantages:

1. It is one of the best methods to acquire relative weights of different attributes.

2. By decomposing and streamlining a complex problem and then reforming it into an organized hierarchy, it helps to elicit opinions from experts.

3. It is easily combined with other techniques to perform further analysis (Saaty, 1990).

In Figure 1, the main goal, located at the topmost level (on the far left side), is to understand the benefits of part-time jobs performed by college students; The second level of the hierarchy consists of three major dimensions-Economic, Social, and Learning; and the third level consists of the 6 benefits.

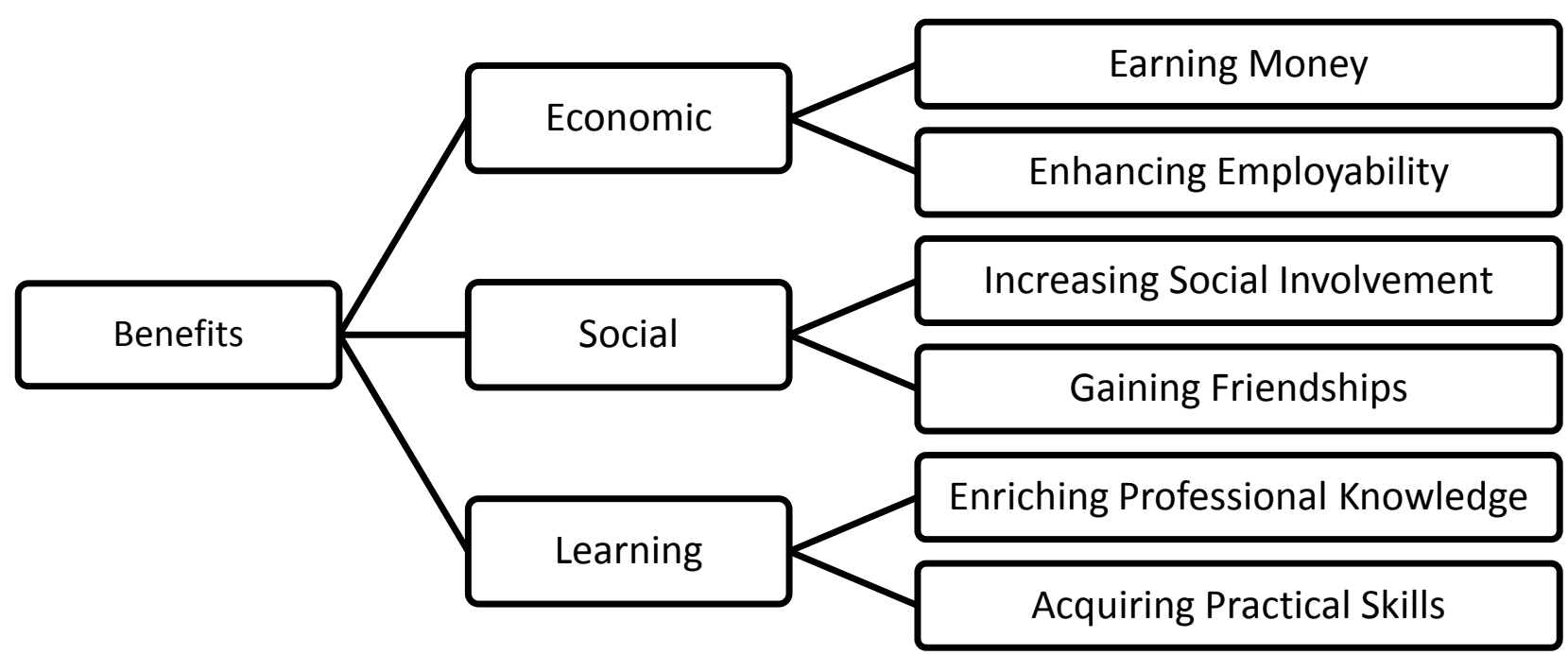

Figure 1: AHP Structure

\section{Design of the Questionnaire}

A self-developed questionnaire was used to explore the perceptions of college students regarding the benefits of part-time jobs performed by them. The questionnaire contained three parts. The first part consisted of questions about the participant's background; the second part consisted of 6 pairs of questions for AHP analysis; and the third part consisted of check list of a 6 times 7 cross-table formed by benefits on types of jobs to investigate the degree of particular benefits bored by different type of jobs. 


\section{Research Participants}

The self-developed questionnaire was administered to 250 college students from 3 universities in Taiwan. A total of 189 were received and valid for analysis, resulting in a 76\% retrieve rate. Of all the participants, 59\% were male and $41 \%$ were female; $70 \%$ had part-time job experiences, while only $30 \%$ did not have any working experience.

\section{RESEARCH RESULTS}

This section begins by presenting the results of AHP, followed by a presentation of the statistics indicating which type of part-time job may benefit most to students' needs.

\section{Results Of AHP}

Microsoft Excel 2010 was adopted for the AHP analyses. Since the second-level AHP analysis contained three alternatives, an eigenvector consistency test was used to confirm the validity. The CR value of the positive matrixes was 0.017, far below the 0.1 judge standard suggested by Saaty (1980), and thus confirming its validity. The results of the second level reveal that Economic Dimension (.439) was the most important dimension inspiring students to take part-time jobs, followed by Learning Dimension (.334) and Social Dimension (.227).

Table 1: Weights of the Three Dimensions

\begin{tabular}{|c|c|l|c|c|}
\hline \multicolumn{1}{|c|}{ First Level } & CR & \multicolumn{1}{|c|}{ Second Level } & Weight & Order \\
\hline \multirow{3}{*}{ Benefits } & \multirow{2}{*}{.017} & Economic & .439 & $(1)$ \\
\cline { 3 - 6 } & \multirow{2}{*}{} & Social & .227 & $(3)$ \\
\cline { 3 - 6 } & & Learning & .334 & $(2)$ \\
\hline
\end{tabular}

Since all three third-level AHP procedures contained less than three alternatives, it is suggested by Saaty (1980) that the consistency is self-evident, and constructing the eigenvector consistency test was an unnecessary action, so we did not perform consistency test for these procedures.

The results for the third level of the AHP analysis (Table 2) show that Earning Money (.248) was the most important purpose for taking part-time job, followed in descending order by Acquiring Practical Skills (.230), Enhancing Employability (.190), Increasing Social Involvement (.141), Enriching Professional Knowledge (.104), and Gaining Friendships (.086).

Table 2: Weights of the Six Benefits

\begin{tabular}{|c|l|l|c|c|}
\hline First Level & \multicolumn{1}{|c|}{ Second Level } & \multicolumn{1}{|c|}{ Third Level } & Weight & Order \\
\hline \multirow{5}{*}{ Benefits } & \multirow{2}{*}{ Economic } & Earning Money & .248 & $(1)$ \\
\cline { 2 - 6 } & & Enhancing Employability & .190 & $(3)$ \\
\cline { 2 - 6 } & \multirow{2}{*}{ Social } & Increasing Social Involvement & .141 & $(4)$ \\
\cline { 2 - 6 } & & Making Friends. & .086 & $(6)$ \\
\cline { 2 - 6 } & \multirow{2}{*}{ Learning } & Enriching Professional Knowledge & .104 & $(5)$ \\
\cline { 3 - 6 } & & Acquiring Practical Skills & .230 & $(2)$ \\
\hline
\end{tabular}

\section{Results Of The Descriptive Statistics}

In the next step we determined which of the 7 types of part-time job best meet the purposes pursuit by students. The average score of each type of part-time job to each purpose was revealed by a cross table below (table 3). The table shows that Tutoring and Office Operation have the most bearing on Earning Money; Office Operation is also beneficial to Enhancing Employability, Culinary Services contribute much to Social Involvement, Tutoring is good for making Friends, Instructional Assistant has the most bearing on Enriching Professional Knowledge, and Office Operation is very helpful to Acquiring Practical Skills. 
Table 3: Type Of Job On Benefits

\begin{tabular}{|l|c|c|c|c|c|c|}
\hline & $\begin{array}{c}\text { Earning } \\
\text { Money }\end{array}$ & $\begin{array}{c}\text { Enhancing } \\
\text { Employability }\end{array}$ & $\begin{array}{c}\text { Increasing Social } \\
\text { Involvement }\end{array}$ & $\begin{array}{c}\text { Making } \\
\text { Friends }\end{array}$ & $\begin{array}{c}\text { Enriching Professional } \\
\text { Knowledge }\end{array}$ & $\begin{array}{c}\text { Acquiring } \\
\text { Practical Skills }\end{array}$ \\
\hline $\begin{array}{l}\text { Instructional } \\
\text { Assistant }\end{array}$ & 2.99 & 3.63 & 3.07 & 2.79 & 4.02 & 3.69 \\
\hline $\begin{array}{l}\text { Administrative } \\
\text { Assistant }\end{array}$ & 3.19 & 3.66 & 3.57 & 2.93 & 3.52 & 3.68 \\
\hline $\begin{array}{l}\text { Laboring } \\
\text { Operation }\end{array}$ & 2.33 & 2.74 & 2.97 & 2.92 & 2.57 & 3.21 \\
\hline $\begin{array}{l}\text { Culinary } \\
\text { Services }\end{array}$ & 3.40 & 3.10 & 3.74 & 3.65 & 3.01 & 3.63 \\
\hline Clerk Services & 3.04 & 2.77 & 3.66 & 3.44 & 2.72 & 3.12 \\
\hline Tutoring & 3.89 & 3.24 & 3.40 & 3.77 & 3.31 & 3.25 \\
\hline $\begin{array}{l}\text { Office } \\
\text { Operation }\end{array}$ & 3.92 & 3.90 & 3.58 & 3.27 & 3.67 & 3.88 \\
\hline
\end{tabular}

Thereafter, we tried to figure out the most beneficial type of job by considering both the results of table 2 and table 3. Multiplications of the original average score to the weights of the purposes were performed, which lead to the weighted total scores of each type of part-time job (see table 4). The results showed that Office Operation is the most lucrative type of job (3.78), followed by Tutoring (3.48), Administrative Assistant (3.46), Culinary Services (3.42), Instructional Assistant (3.38), Clerk Services (3.10), and Laboring Operations (2.77).

Table 4: Weighted Score Of Type Of Job

\begin{tabular}{|l|c|c|c|c|c|c|c|}
\hline & $\begin{array}{c}\text { Earning } \\
\text { Money }\end{array}$ & $\begin{array}{c}\text { Enhancing } \\
\text { Employability }\end{array}$ & $\begin{array}{c}\text { Increasing Social } \\
\text { Involvement }\end{array}$ & $\begin{array}{c}\text { Making } \\
\text { Friends }\end{array}$ & $\begin{array}{c}\text { Enriching Professional } \\
\text { Knowledge }\end{array}$ & $\begin{array}{c}\text { Acquiring } \\
\text { Practical Skills }\end{array}$ & Total \\
\hline $\begin{array}{l}\text { Instructional } \\
\text { Assistant }\end{array}$ & 0.74 & 0.69 & 0.43 & 0.24 & 0.42 & 0.85 & 3.38 \\
\hline $\begin{array}{l}\text { Administrative } \\
\text { Assistant }\end{array}$ & 0.79 & 0.70 & 0.50 & 0.25 & 0.37 & 0.85 & 3.46 \\
\hline $\begin{array}{l}\text { Laboring } \\
\text { Operation }\end{array}$ & 0.58 & 0.52 & 0.42 & 0.25 & 0.27 & 0.74 & 2.77 \\
\hline $\begin{array}{l}\text { Culinary } \\
\text { Services }\end{array}$ & 0.84 & 0.59 & 0.53 & 0.32 & 0.31 & 0.84 & 3.42 \\
\hline Clerk Services & 0.76 & 0.53 & 0.52 & 0.30 & 0.28 & 0.72 & 3.10 \\
\hline Tutoring & 0.97 & 0.62 & 0.48 & 0.33 & 0.34 & 0.75 & 3.48 \\
\hline $\begin{array}{l}\text { Office } \\
\text { Operation }\end{array}$ & 0.97 & 0.74 & 0.50 & 0.28 & 0.38 & 0.89 & 3.78 \\
\hline
\end{tabular}

\section{CONCLUSION}

This research aimed to determine the benefits of part-time jobs performed by college students, calculate their relative benefits, and determine the particular functions of different types of part-time jobs.

Understanding that each strategy bearing different importance and those different strategies contribute differently to certain benefits can help student to select the most appropriate type of job for a given purpose. The results of the cross-table also show that Tutoring and Office Operation have the most bearing on Earning Money; Office Operation is also beneficial to Enhancing Employability, Culinary Services contribute much to Social Involvement, Tutoring is good for Making Friends, Instructional Assistant has the most bearing on Enriching Professional Knowledge, and Office Operation is very helpful to Acquiring Practical Skills.

The AHP results showed that the benefits of part-time employment most stressed by students are Earning Money and Acquiring Practical Skills. The results of the cross table showed that the most effective way of addressing the former is by Tutoring Students and Taking Office Operational Jobs, and the best way of addressing the latter is by Taking Office Operational Jobs. Hence, taking Office Operational Jobs is most beneficial to students, and this result coincide with the result of the analysis of weighted score of type of jobs, which also indicate that Taking Office Operational Jobs is most advantageous to students. Therefore, Schools may consider to creating and 
providing more part-time office operational job opportunities for their students if the aim is to enhance students' well-being.

\section{AUTHOR INFORMATION}

Cheng Cheng Yang, National Chiayi University, Taiwan. E-mail: yccjason@ mail.ncyu.edu.tw

Hsuan-Fu Ho, National Chiayi Universiry, Taiwan. E-mail: hfho@mail.ncyu.edu.tw (Corresponding author)

Shan-Hua Chen, National Chiayi University, Taiwan. E-mail: shanhua@ mail.ncyu.edu.tw

\section{REFERENCES}

1. Astin, A. W. (1999). Student involvement: A developmental theory for higher education. Journal of College Student Development, 40(5), 518-529.

2. Christou, C., and Haliassos, M. (2006). How do students finance human capital accumulation?: The choice between borrowing and work. Journal of Policy Modeling, 28(1), 39-51.

3. Derous, E. and Ryan, A. M. (2008). When earning is beneficial for learning: The relation of employment and leisure activities to academic outcomes. Journal of Vocational Behavior, 73(1), 118-131.

4. $\quad$ Ehrenberg, R. \& Sherman, D. (1987). Employment while in college, academic achievement, and postcollege outcomes. Journal of Human Resources, 22(1), 1-24.

5. Gault, J., Redington, J., \& Schlager T. (2000). Undergraduate business internships and career success: Are they related? Journal of Marketing Education, 22(1), 45-53.

6. Hakkinen, L. (2006). Working while enrolled in auniversity: does it pay? Labour Economics, 13(2), 167189.

7. Kuh, G. D. (1995). The other curriculum: Out-of-class experiences associated with student learning and personal development. The Journal of Higher Education, 66(2), 123-155.

8. Laberge, L., Ledoux, E., Auclair, J., Thuilier, C., Gaudreault, M., Gaudreault, M, Veillette, S., and Perron, M. (2011). Risk factors for work-related fatigue in students with school-year employment. Journal of Adolescent Health, 48(3), 289-294.

9. Miller, B. (2010). The price of higher education: how rational is British tuition fee policy. Journal of Higher Education Policy and Management, 32(1), 85-95.

10. Pinquart, M., Juang, L. P., and Silbereisen, R. K. (2003). Self-efficacy and successful school-to-work transition: A longitudinal study. Journal of Vocational Behavior, 63(3), 329-346.

11. Paul, H. (1982). The impact of outside employment on student achievement in macroeconomic principles. Journal of Economic Education, 13, 51-56.

12. Saaty, T. L. (1990). Decision making for leaders: The analytic hierarchy process for decisions in a complex world. Pittsburgh, PA: RWS Publications. 
NOTES 